\title{
The influence of food supply on the response of Olympia oyster larvae to ocean acidification
}

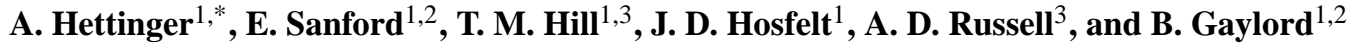 \\ ${ }^{1}$ Bodega Marine Laboratory, University of California, Davis, 2099 Westshore Road, Bodega Bay, CA 94923, USA \\ ${ }^{2}$ Department of Evolution and Ecology, University of California, Davis, One Shields Avenue, Davis, CA 95616, USA \\ ${ }^{3}$ Department of Geology, University of California, Davis, One Shields Avenue, Davis, CA 95616, USA \\ * current address: Department of Zoology, Oregon State University, 3029 Cordley Hall, Corvallis, OR 97331, USA
}

Correspondence to: A. Hettinger (hettinan@science.oregonstate.edu)

Received: 10 February 2013 - Published in Biogeosciences Discuss.: 25 March 2013

Revised: 23 August 2013 - Accepted: 16 September 2013 - Published: 23 October 2013

\begin{abstract}
Increases in atmospheric carbon dioxide drive accompanying changes in the marine carbonate system as carbon dioxide $\left(\mathrm{CO}_{2}\right)$ enters seawater and alters ocean $\mathrm{pH}$ (termed "ocean acidification"). However, such changes do not occur in isolation, and other environmental factors have the potential to modulate the consequences of altered ocean chemistry. Given that physiological mechanisms used by organisms to confront acidification can be energetically costly, we explored the potential for food supply to influence the response of Olympia oyster (Ostrea lurida) larvae to ocean acidification. In laboratory experiments, we reared oyster larvae under a factorial combination of $p \mathrm{CO}_{2}$ and food level. Elevated $p \mathrm{CO}_{2}$ had negative effects on larval growth, total dry weight, and metamorphic success, but high food availability partially offset these influences. The combination of elevated $p \mathrm{CO}_{2}$ and low food availability led to the greatest reduction in larval performance. However, the effects of food and $p \mathrm{CO}_{2}$ interacted additively rather than synergistically, indicating that they operated independently. Despite the potential for abundant resources to counteract the consequences of ocean acidification, impacts were never completely negated, suggesting that even under conditions of enhanced primary production and elevated food availability, impacts of ocean acidification may still accrue in some consumers.
\end{abstract}

\section{Introduction}

Global mean atmospheric carbon dioxide $\left(\mathrm{CO}_{2}\right)$ concentrations have increased by nearly $40 \%$ from 280 parts per million (ppm) during preindustrial times to approximately $390 \mathrm{ppm}$ by the year 2010 (Doney, 2010). The equivalent of nearly $30 \%$ of total human-derived $\mathrm{CO}_{2}$ emissions have entered the world's oceans, altering ocean chemistry and leading to more acidic seawater with lower carbonate ion $\left[\mathrm{CO}_{3}^{2-}\right]$ concentrations (Sabine et al., 2004). Studies have demonstrated that this "ocean acidification" affects a spectrum of organismal traits, including but not limited to growth, reproduction, development, shell strength, skeletal composition, and survival (e.g., Kurihara et al., 2007; Gaylord et al., 2011; LaVigne et al., 2013), across a diversity of taxa (Doney et al., 2009; Kroeker et al., 2010, 2013; Gazeau et al., 2013). There have been fewer studies examining how impacts might be influenced by accompanying shifts in other environmental factors; most have focused on combined effects of altered $\mathrm{pH} / p \mathrm{CO}_{2}$ and temperature (reviewed by Byrne, 2011). However, other environmental factors, such as salinity, dissolved oxygen, and patterns of primary production are also predicted to diverge from present values (Behrenfeld et al., 2006; Harley et al., 2006; Riebesell et al., 2007; Diaz and Rosenberg, 2008; Doney, 2010).

The consequences of such multifaceted changes may be particularly dramatic in nearshore environments. This could be especially true in areas where the upwelling process, which brings waters that are naturally $p \mathrm{CO}_{2}$-rich to the surface, already exposes coastal benthic marine invertebrate 
species to waters low in $\mathrm{pH}$ and carbonate concentrations (Feely et al., 2008, 2010; Barton et al., 2012; Gruber et al., 2011, 2012). Moreover, some models and time series data project an enhancement in the intensity of upwelling, as may be the case for the California Current System of the eastern Pacific (Bakun, 1990; Snyder et al., 2003; García-Reyes and Largier, 2010). Altered water temperature and nutrients, coupled with ocean acidification, may influence phytoplankton productivity (Rose et al., 2009), a food source for pelagic planktotrophic larval stages (Phillips and Gaines, 2002).

In marine systems, the planktonic food environment influences larval condition, and is one of a suite of interacting variables that affects larval and juvenile quality (Phillips, 2002; Boidron-Métairon, 1995; Pace and Manahan, 2007; Giménez, 2010; Vargas et al., 2006, 2013). Furthermore, the ability of planktotrophic larvae to ingest a range of food particle sizes and types (e.g., Baldwin and Newell, 1995) could influence larval responses to ocean acidificationinduced shifts in the biochemical and taxonomic composition of phytoplankton. There are mechanisms by which ocean productivity could moderate ocean acidification impacts on planktotrophic larvae. First, ocean acidification may induce changes in phytoplankton growth, inorganic carbon uptake, nitrogen fixation, and elemental ratios (Berge et al., 2010; Reinfelder, 2012), each of which could reduce the nutritional food quality for planktotrophic larvae and other consumers (Riebesell et al., 2007; Rossoll et al., 2012; Reinfelder, 2012). Secondly, ocean acidification could also alter the taxonomic composition of phytoplankton assemblages through a combination of direct and indirect effects (Rose et al., 2009; Caron and Hutchins, 2013). Such shifts may be important because larval performance in oysters and other invertebrates is often sensitive to phytoplankton composition (Thompson et al., 1993; Talmage and Gobler, 2012; Vargas et al., 2013). These shifts would operate in addition to upwelling-induced phytoplankton blooms directly altering seawater chemistry by drawing down total $\mathrm{CO}_{2}$ through enhanced rates of photosynthesis, shifting carbonate and $\mathrm{pH}$ levels back towards conditions favorable for marine invertebrate shell and skeleton-building (Hauri et al., 2009).

Surmounting low $\mathrm{pH}$ conditions can incur increased energetic costs, and thus changes in food supply might modulate the effects of ocean acidification on marine taxa across life history stages. Nevertheless, few experiments have been performed to determine whether improved nutrition might ameliorate the negative effects of ocean acidification or whether impaired nutrition might exacerbate these effects. Among the studies that have been conducted on bivalves, Melzner et al. (2011) found greater internal shell dissolution of adult mussels when individuals were exposed to high $p \mathrm{CO}_{2}$ and low food density. Examining a different life stage of the same mussel species, Thomsen et al. (2013) found that mussels were able to overcome exposure to high $p \mathrm{CO}_{2}$ during the juvenile phase if there was sufficient food available in the environment.
A remaining unknown is how larval responses to elevated $p \mathrm{CO}_{2}$ might change as a function of food availability. Ocean acidification has been shown to affect larvae and the larvalto-juvenile transition in bivalves (e.g., Talmage and Gobler, 2009; Parker et al., 2010; Barton et al., 2012), and research indicates that energetic stresses imposed during the larval phase (including those from elevated $p \mathrm{CO}_{2}$ ) can influence latter life stages (e.g., Rodriguez et al., 1990; Videla et al., 1998; Pechenik, 2006; Hettinger et al., 2012, 2013). Less clear is the degree to which plentiful food might counteract any or all of these impacts. To address this, we exposed larval Olympia oysters (O. lurida) to a factorial combination of food and $p \mathrm{CO}_{2}$ regimes, tracked growth over the full pelagic duration, and determined percent metamorphosis.

\section{Methods}

\subsection{Study system}

Olympia oysters (Ostrea lurida) are native to bays and estuaries along the northeast Pacific coast from Alaska to Baja California Sur, Mexico (Baker, 1995). Olympia oysters are a brooding species, and females collect sperm from the water column to fertilize their eggs. Developing trochophore larvae are brooded for approximately 10 days in the mantle cavity before being released by the female as veliger larvae. Veliger larvae develop for 2-3 weeks before they settle and metamorphose into juveniles cemented to hard substrate with one valve of the shell (Baker, 1995).

\subsection{Larval culture maintenance}

Adult Olympia oysters $(n=140)$ were collected from Tomales Bay, California $\left(38^{\circ} 06^{\prime} 58^{\prime \prime} \mathrm{N}, 122^{\circ} 51^{\prime} 16^{\prime \prime} \mathrm{W}\right)$ in June 2011, transported to Bodega Marine Laboratory (BML), Bodega Bay, California, cleaned of all epiphytes, and distributed evenly among four $100 \mathrm{~L}$ culturing cylinders. A similar average size of adult oysters was maintained among cylinders. Every day, adults in each cylinder were fed microalgae (Isochrysis galbana) at a concentration of approximately 200000 cells $\mathrm{mL}^{-1}$; such high food levels encourage larval release. Seawater, filtered to $0.45 \mu \mathrm{m}$ and held at 18 $22^{\circ} \mathrm{C}$, was changed every other day. Seawater in the cylinders was not altered with respect to $p \mathrm{CO}_{2}$ concentrations, and was bubbled with air to maintain oxygen levels and induce water motion. Adults released larvae in two of the four culturing cylinders after $72 \mathrm{~h}$. Within $12 \mathrm{~h}$ of their release, larvae were distributed by pipette to $4.5 \mathrm{~L}$ glass jars on day 1 of the experiment ( $n=1000$ larvae per jar), for subsequent rearing through the full pelagic larval period. Each jar held $2 \mathrm{~L}$ of filtered seawater at the appropriate $p \mathrm{CO}_{2}$ level, resulting in initial rearing concentrations of 1 larva per $2 \mathrm{~mL}$ of seawater.

In subsequent experimental trials, we employed a target elevated seawater $p \mathrm{CO}_{2}$ concentration of $1000 \mu \mathrm{atm}$ 
$\left(\sim 7.76 \mathrm{pH}_{\mathrm{T}}\right)$. This level of $p \mathrm{CO}_{2}$ is found currently in upwelled waters off the northern California coast (Feely et al., 2008), and these upwelled waters can enter Tomales Bay during the time when oyster larvae are in the water column, bringing low $\mathrm{pH}$ waters as far as $8-10 \mathrm{~km}$ into the bay (A. D. Russell, unpublished data). The target control seawater $p \mathrm{CO}_{2}$ concentration was $500 \mu$ atm $\left(\sim 8.05 \mathrm{pH}_{\mathrm{T}}\right)$, approximating an average seawater $p \mathrm{CO}_{2}$ level that occurs presently during the summer months in Tomales Bay (A. D. Russell, unpublished data). All seawater used during larval rearing was pre-adjusted, prior to addition of larvae, to the appropriate $p \mathrm{CO}_{2}$ concentrations in $20 \mathrm{~L}$ carboys by bubbling filtered seawater for 2-3 days with NIST-traceable $\mathrm{CO}_{2}$ air mixtures (carboy water). To minimize net $\mathrm{CO}_{2}$ exchange across the seawater surfaces in the jars and help maintain seawater $p \mathrm{CO}_{2}$ concentrations at target levels within the jars, the same $\mathrm{CO}_{2}$ gas mixtures used to maintain carboy water were pumped continuously into sealed air spaces above the free surfaces of the seawater in the culture jars (hereafter "headspaces"). Five replicate jars per $p \mathrm{CO}_{2}$ concentration shared a given headspace. Carboys and jars were held in seawater tables maintained at $20^{\circ} \mathrm{C}\left( \pm 0.2^{\circ} \mathrm{C}\right)$, within the natural temperature range in our study region during summer months when Olympia oyster larvae are in the water column (Smith and Hollibaugh, 1997). Additional details of the larval culturing apparatus can be found in Hettinger et al. (2012).

Every other day, $90 \%$ of the seawater in each jar (jar water) was removed using reverse-filtration through $125 \mu \mathrm{m}$ mesh and replaced with carboy water at the target $p \mathrm{CO}_{2}$ concentration. Immediately following each water change, microalgae (I. galbana) were added to each jar to generate final densities in each jar of: 100000,50000 , or 10000 cells $\mathrm{mL}^{-1}\left(n=2 \quad p \mathrm{CO}_{2}\right.$ levels $\times 3$ food levels $\times 5$ replicate jars $=30$ jars). The three food levels were the equivalent of initial daily algal cell to larva ratios of 50,25, and 5 cells per larva per day. The highest level is known to encourage rapid growth and high survival of larval and juvenile oysters in culture (Strathmann, 1987). In our study region during the time when Olympia oyster larvae are in the water column, field measurements suggest chlorophyll $a$ concentrations of $10-15 \mathrm{mg} \mathrm{m}^{-3}$ arise commonly, the lower limit of which approximates our high food level (100 000 cells $\mathrm{mL}^{-1}$; $\sim 10 \mathrm{mg} \mathrm{m}^{-3}$ ) (Kimbro et al., 2009; B. S. Cheng, unpublished data).

To take into account that elevated $p \mathrm{CO}_{2}$ concentrations and the algal growth phase can induce shifts in phytoplankton biochemical composition, with possible consequences for consumer nutrition (e.g., Engel et al., 2008; Bellerby et al., 2008; Reinfelder, 2012), we cultured I. galbana under control $p \mathrm{CO}_{2}$ conditions and added algae to our larval cultures when algal cultures were at peak densities. Examination of a subsample of algal cells and cell counts were performed every other day under the microscope prior to preparing algae to feed larvae. Algal cultures were not used if they ap- peared to have many dead cells or any contamination by other microorganisms, an indication that cultures were in decline. Presumably, the majority of I. galbana cells were consumed before any potential effect of elevated $p \mathrm{CO}_{2}$ significantly influenced their quality. I. galbana remaining in larval cultures were removed during water changes every other day.

A set of modified glass jars (substrate jars) was constructed for ease of quantifying larval settlement and metamorphosis by removing the bases from a new set of jars, replacing the bases with grey PVC plates ( $5 \mathrm{~mm}$ thick) attached with aquarium-safe silicone, and conditioning the new jar bases in filtered seawater for 2 days. Each PVC plate was roughened with sandpaper to encourage settlement, and a $1 \mathrm{~cm}^{2}$ grid was drawn onto each base to assist with quantifying settlement and metamorphosis. On day 9 of the experiment, prior to the commencement of settlement and metamorphosis, larvae were transferred into substrate jars. Following metamorphosis, the PVC plates were removed from the jars and percent metamorphosis was quantified (see Sect. 2.6 for details).

\subsection{Seawater chemistry during larval culturing}

Jar water (previously containing larvae and microalgae) and carboy water (no larvae or microalgae) were sampled for total alkalinity (TA) and dissolved inorganic carbon (DIC) every other day when a water change was performed. Seawater $\mathrm{pH}$ and temperature were measured using a potentiometric $\mathrm{pH} /$ temperature meter (Accumet Excel XL60). Raw pH readings $(\mathrm{mV})$ were calibrated using two seawater buffers (2amino-2-hydroxymethyl-1,3-propanediol ("TRIS") and 2aminopyridine/HCl ("AMP") in synthetic seawater). These buffers were made in-house following Dickson et al. (2007) and checked against a certified TRIS buffer (A. Dickson, Scripps Institute of Oceanography, La Jolla, California). $\mathrm{pH}$ was monitored primarily as a real-time indicator of changes in the carbonate system. Salinity was determined using a YSI Professional Plus multiparameter instrument with a conductivity probe calibrated in a NIST-traceable conductivity calibration solution (YSI, Yellow Springs, OH). TA was measured using automated Gran titration with duplicates (Metrohm 809), and standardized using certified reference material (CRM) from A. Dickson. The offset between measured and certified TA values for Dickson CRM (Batches $104,107,111)$ was $-0.01( \pm 2.81) \mathrm{meq} \mathrm{kg}^{-1}(n=91)$. A subset of samples was analyzed for DIC at the University of Georgia's infrared $\mathrm{CO}_{2}$ analysis facility (Cai and Wang, 1998). Other carbonate system parameters (calcite and aragonite saturation states: $\Omega_{\text {calcite }}, \Omega_{\text {aragonite }}$ and seawater $p \mathrm{CO}_{2}$ ) were calculated using the carbonate system analysis software CO2SYS (Lewis and Wallace, 1998) employing DIC and TA as the primary input variables, with equilibrium constants K1 and K2 taken from Mehrbach et al. (1973) refit by Dickson and Millero (1987), and $\mathrm{KSO}_{4}$ from Dickson (1990). 


\subsection{Sampling of larval growth}

Larval oysters in the culture jars were sampled at key time points to quantify growth through the larval duration. On day 1 , prior to their placement in the culture jars, larvae were collected haphazardly by pipette $(n=20)$, placed on a $125 \mu \mathrm{m}$ Nitex plankton filter, rinsed twice with distilled water, with all excess distilled water wicked immediately through the back of the filter, and left to dry at room temperature for $24 \mathrm{~h}$. Larvae were photographed individually under a dissecting microscope (Leica M125 with DC290 camera) for analysis using ImageJ software (ver. 1.37, National Institutes of Health) to determine the initial projected area of the shell. Larvae were sampled and their projected areas were determined similarly on day 5, 9, and 11 post-larval release ( $n=10$ larvae per jar at each time point). Larval growth was estimated as the change in projected shell area since larval release (day 1 ).

\subsection{Sampling of larval total dry weight}

Total dry weight (body plus shell, $\mu \mathrm{g}$ ) of the oysters was also determined on days 5, 9, and 11 post larval release. Larvae were collected haphazardly by pipette from each jar $(n=25)$, placed on a $125 \mu \mathrm{m}$ Nitex plankton filter, and were rinsed twice and dried as described above. Total dry weights of larvae sampled were determined by transferring larvae individually to aluminum vessels pre-ashed at $500^{\circ} \mathrm{C}$ for $3 \mathrm{~h}$, drying the larval sample at $50^{\circ} \mathrm{C}$ for $>24 \mathrm{~h}$, and weighing on a microbalance (Sartorius Ultramicro, Goettingen, Germany). Larvae were dried in their vessels a second time, reweighed to verify their weights, and combusted at $460{ }^{\circ} \mathrm{C}$ for $4 \mathrm{~h}$ in a muffle furnace (Thermo Scientific FB1415M) to remove all organic matter (see also Gaylord et al., 2011). Ash-free dry tissue weights were determined from the weight difference before and after combusting.

\subsection{Sampling of percent metamorphosis}

Settlement of larvae and metamorphosis into benthic juveniles was assessed daily starting on day 11 , two days after larval transfers were made into the substrate jars. When $<5 \%$ of larvae remained swimming (used as our assay point for settlement) in each $p \mathrm{CO}_{2}$ treatment, the bases of each substrate jar were removed, and the proportion of metamorphosed individuals was determined by first subtracting dead and non-metamorphosed larvae (e.g., pediveligers) from the total initial number of larvae, then dividing by the total initial number of larvae (1000). Any metamorphosed individuals on the walls of the glass jars were also included in the proportion of metamorphosed individuals.

\subsection{Statistical analyses}

Larval growth, total dry weight, and percent metamorphosis were analyzed using separate, partly nested ANOVAs.
The measurements we took on individual larva were subsamples, thus we considered the jars to be our sampling unit, and analyzed mean responses from each jar using ANOVA to avoid pseudoreplication. We employed a split-plot design, where $p \mathrm{CO}_{2}$ level was the whole-plot factor, food level was the sub-plot factor, and headspaces were nested within $p \mathrm{CO}_{2}$ level (Underwood, 1997). Any biological processes occurring within each jar and any resultant effect on seawater chemistry within each jar operated independent of the headspace. However, because the jars were nested within the headspaces, we included the term "headspace $\left[p \mathrm{CO}_{2}\right]$ " in our design as a test for any potential differences. The water chemistry data were analyzed using this same ANOVA structure, and separate ANOVAs were conducted for $\mathrm{pH}$ and TA. For each jar, all measurements of jar water and carboy water were averaged across the experiment, and an ANOVA was conducted on these estimates of the average conditions in each jar. In all analyses, data fulfilled assumptions of normality and homogeneity of variance, tested using Shapiro-Wilks' and Bartlett's test, respectively, and thus untransformed data were used. The statistical software JMP (ver. 8.0.1, Statistical Analysis Software) was used for all analyses.

\section{Results}

\subsection{Seawater chemistry during larval culturing}

$\mathrm{pH}$ values in the $p \mathrm{CO}_{2}$ treatments differed from one another (ANOVA, $p \mathrm{CO}_{2}, F_{1,12}=22850.5, p<0.0001$; Table 1). $\mathrm{pH}$ of jars within headspaces assigned to the same treatment also varied slightly (ANOVA, headspace $\left[p \mathrm{CO}_{2}\right]$, $\left.F_{4,12}=6.66, p<0.005\right)$. Specifically, mean $\mathrm{pH}$ in the jars from headspace 1 in the $500 \mu$ atm $p \mathrm{CO}_{2}$ treatment differed from headspaces 2 and 3 by $0.009 \mathrm{pH}$ unit. $\mathrm{pH}$ levels across the three headspaces in the $1000 \mu$ atm $p \mathrm{CO}_{2}$ level did not differ. $\mathrm{pH}$ values also differed as a function of food level (ANOVA, food, $F_{2,12}=33.82, p<0.0001$; Table 1). $\mathrm{pH}$ units decreased approximately 0.01 unit between each of the subsequent food levels in both $p \mathrm{CO}_{2}$ levels (i.e., the high food level had a $\mathrm{pH}$ unit $\sim 0.01$ lower than the medium food level and the medium food level had a $\mathrm{pH}$ unit $\sim 0.01$ lower than the low food level). This pattern of decreasing $\mathrm{pH}$ with increasing food levels (i.e., algal concentrations) was likely from increased respiration in treatments with higher concentrations of algae, given the low-light conditions that characterized our cultures. Total alkalinity did not differ between the $p \mathrm{CO}_{2}$ treatments (ANOVA, $p \mathrm{CO}_{2}, F_{1,12}=0.38$, $p=0.547$ ), among food levels (ANOVA, food, $F_{2,12}=0.41$, $p=0.675$ ) (Table 1), or among the headspaces assigned to the same treatments (ANOVA, headspace[ $\left.p \mathrm{CO}_{2}\right], F_{4,12}=$ $0.30, p=0.871)$. DIC samples were used simply to overconstrain the carbonate system and were not analyzed statistically. 
Table 1. A table of seawater properties of the two seawater $p \mathrm{CO}_{2}$ regimes during the culturing experiment ( \pm s.d. computed from averages of the jar replicates).

\begin{tabular}{lllllll}
\hline $\begin{array}{l}\text { Food } \\
\text { Level }\end{array}$ & $\begin{array}{l}\mathrm{TA} \\
\left(\mu \mathrm{mol} \mathrm{kg} \mathrm{sw}^{-1}\right)\end{array}$ & $\begin{array}{l}\mathrm{DIC} \\
\left(\mu \mathrm{mol} \mathrm{kg} \mathrm{sw}^{-1}\right)\end{array}$ & $\mathrm{pH}$ & $p \mathrm{CO}_{2 \text { calc }}$ & $\Omega_{\text {calc. }}$ & $\Omega_{\text {arag. }}$ \\
\hline \multicolumn{7}{c}{$500 \mu \mathrm{atm}$} \\
\hline High & $2242 \pm 12(18)$ & $2046 \pm 13(18)$ & $8.05 \pm 0.008$ & $539 \pm 73$ & $3.3 \pm 0.4$ & $2.2 \pm 0.2$ \\
Med & $2240 \pm 13(18)$ & $2040 \pm 17(18)$ & $8.06 \pm 0.005$ & $528 \pm 91$ & $3.4 \pm 0.4$ & $2.2 \pm 0.2$ \\
Low & $2243 \pm 13(18)$ & $2036 \pm 11(18)$ & $8.06 \pm 0.004$ & $494 \pm 69$ & $3.6 \pm 0.3$ & $2.3 \pm 0.3$ \\
\hline \multicolumn{7}{c}{$1000 \mu \mathrm{atm}$} \\
High & $2244 \pm 11(18)$ & $2165 \pm 13(18)$ & $7.75 \pm 0.005$ & $1094 \pm 118$ & $1.9 \pm 0.2$ & $1.2 \pm 0.1$ \\
Med & $2245 \pm 11(18)$ & $2163 \pm 11(18)$ & $7.76 \pm 0.002$ & $1067 \pm 94$ & $2.0 \pm 0.2$ & $1.3 \pm 0.1$ \\
Low & $2246 \pm 12(18)$ & $2165 \pm 8(18)$ & $7.76 \pm 0.004$ & $1065 \pm 102$ & $2.0 \pm 0.2$ & $1.3 \pm 0.1$ \\
\hline
\end{tabular}

The number of samples for TA and DIC are indicated in parentheses.

Temperature and salinity (mean \pm s.d.) were $19.4 \pm 0.05^{\circ} \mathrm{C}$ and $33.4 \pm 0.46$, respectively.

TA, total alkalinity; DIC, dissolved inorganic carbon.

\subsection{Larval growth}

Larval growth on day 5 post-larval release was reduced in low compared to medium food levels (ANOVA, $p=0.039$ ), but did not differ between the two $p \mathrm{CO}_{2}$ concentrations (ANOVA, $p=0.092$; Table S1, Fig. 1a). Similar patterns were exhibited on day 9; however, at this time point, growth was reduced in low compared to medium and high food levels (ANOVA, food, $p=0.002 ; p \mathrm{CO}_{2}, p=0.175$; Table S2, Fig. 1b). At day 11, growth was reduced in low food compared to medium and high food levels (ANOVA, $p=0.048)$ and also in high compared to control $p \mathrm{CO}_{2}$ conditions (ANOVA, $p=0.047$; Table S3, Fig. 1c). Indeed, larval growth was $9 \%, 5 \%$, and $14 \%$ higher in control compared to high $p \mathrm{CO}_{2}$ conditions, for the high, medium, and low food treatments, respectively. The effects of food on larval growth were consistent regardless of $p \mathrm{CO}_{2}$ concentration (ANOVA, $p \mathrm{CO}_{2} \times$ food, Day 5, $p=0.778$; Day 9, $p=0.962$; Day 11, $p=0.720$; Table S1-S3). Larval growth did not vary between headspaces assigned to the same treatment (Table S1-S3).

\subsection{Larval total dry weight}

On day 5 post-larval release, total dry weight was reduced in low compared to medium food levels (ANOVA, $p=0.001$ ) and was also reduced in elevated compared to control $p \mathrm{CO}_{2}$ conditions (ANOVA, $p=0.002$; Table S4, Fig. 2a). On day 9 , low food decreased total dry weight compared to medium and high food levels (ANOVA, $p=0.003$ ), but $p \mathrm{CO}_{2}$ concentration did not have an effect (ANOVA, $p=0.206$; Table S5, Fig. 2b). The same patterns were exhibited on day 11 for low food (ANOVA, $p<0.0001$ ) and $p \mathrm{CO}_{2}$ concentration (ANOVA, $p=0.089$; Table S6, Fig. 2c). The effect of $p \mathrm{CO}_{2}$ on total dry weight was dependent on food level on day 5 (ANOVA, $p \mathrm{CO}_{2} \times$ food, $p=0.001$ ), but not day 9 (ANOVA, $p=0.448$ ) or day 11 (ANOVA, $p=0.782$; Table S4-S6).
The significant interaction on day 5 is likely from the particularly high weights in the ambient $p \mathrm{CO}_{2} /$ medium food level treatment.

\subsection{Percent metamorphosis}

Settlement occurred on day 16 in the high and medium food treatments in both $p \mathrm{CO}_{2}$ concentrations, on day 19 in the low food/control $p \mathrm{CO}_{2}$ treatment, and on day 22 in the low food/elevated $p \mathrm{CO}_{2}$ treatment. On average, across all food treatments, percent metamorphosis was $70 \%$ higher in control compared to high $p \mathrm{CO}_{2}$ concentrations (ANOVA, $p<0.0001$; Table S7, Fig. 3). There was also a significant effect of food level on percent metamorphosis, which was reduced in the low compared to the medium and high food levels (ANOVA, $p=0.01$; Table S7, Fig. 3). Percent metamorphosis was $40 \%$ higher in the control $p \mathrm{CO}_{2} /$ high food compared to the control $p \mathrm{CO}_{2} /$ low food treatments, and $54 \%$ higher for the high $p \mathrm{CO}_{2} /$ high food compared to the high $p \mathrm{CO}_{2} /$ low food treatments. The effect of $p \mathrm{CO}_{2}$ level on settlement was consistent across the three food levels (ANOVA, $p \mathrm{CO}_{2} \times$ food, $p=0.226$; Table S7).

\section{Discussion}

Ocean acidification-induced reductions in growth and calcification have been reported across all life stages of bivalve species (e.g., Ries et al., 2009; Miller et al., 2009; Waldbusser et al., 2010; Gaylord et al., 2011; Hettinger et al., 2012; Gazeau et al., 2013). Several mechanisms are thought to drive such responses including altered metabolic rates and modified energy budget allocation (Pörtner et al., 2004; Michaelidis et al., 2005; Wood et al., 2008; Melzner et al., 2011; Waldbusser et al., 2013). However, studies explicitly testing whether increased food supply might counteract the negative effects of elevated $p \mathrm{CO}_{2}$ focus primarily on adult or 


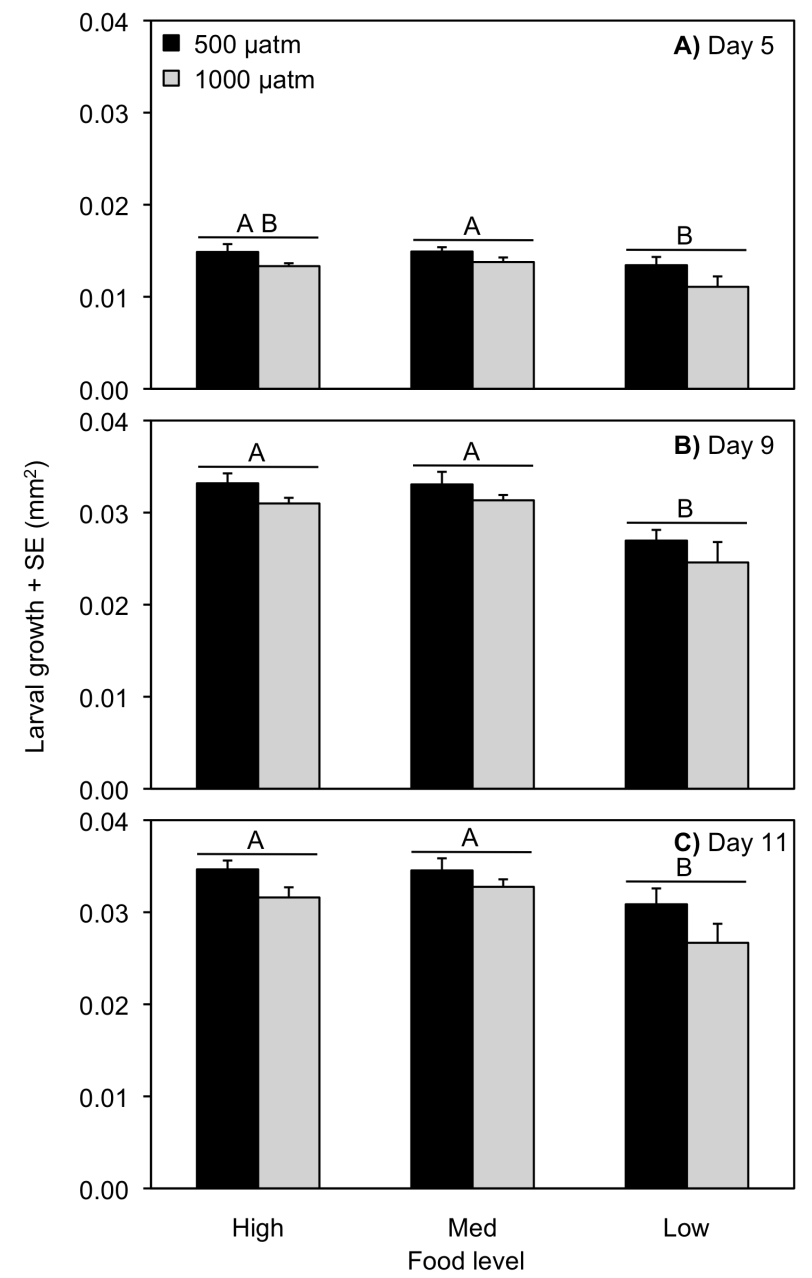

Fig. 1. Effect of $p \mathrm{CO}_{2}$ and food supply on larval growth in Olympia oysters (Ostrea lurida). Data are shell growth on (A) day 5, (B) day 9 , and (C) day 11 post-larval release in control (black bars) and elevated (grey bars) $p \mathrm{CO}_{2}$ levels. Food levels in each treatment relate to the following concentrations: 100000 cells $\mathrm{mL}^{-1}$ (High), 50000 cells $\mathrm{mL}^{-1}$ (Med), 10000 cells $\mathrm{mL}^{-1}$ (Low), and refer to the density of Isochrysis galbana in each jar per treatment. Values are means across all jar replicates of a given treatment $+1 \mathrm{SE}$. Shared letters above bars indicate food levels that did not differ significantly (Tukey HSD, $p>0.05$ ).

juvenile life stages (e.g., Holcomb et al., 2010 (adult corals); Edmunds, 2011 (adult corals); Melzner et al., 2011 (adult mussels); Comeau et al., 2013 (adult corals); Thomsen et al., 2013 (juvenile mussels)). Our limited knowledge of the possible interactive effects of food supply and ocean acidification on larval life stages hampers our ability to predict consequences of global change for natural populations, especially in areas where oceanographic processes create seasonally dynamic conditions of waters that can be depleted in phytoplankton and low in $\mathrm{pH}$.

Eastern boundary upwelling ecosystems (areas bathed by the California, Benguela, Humboldt, and Canary Currents)
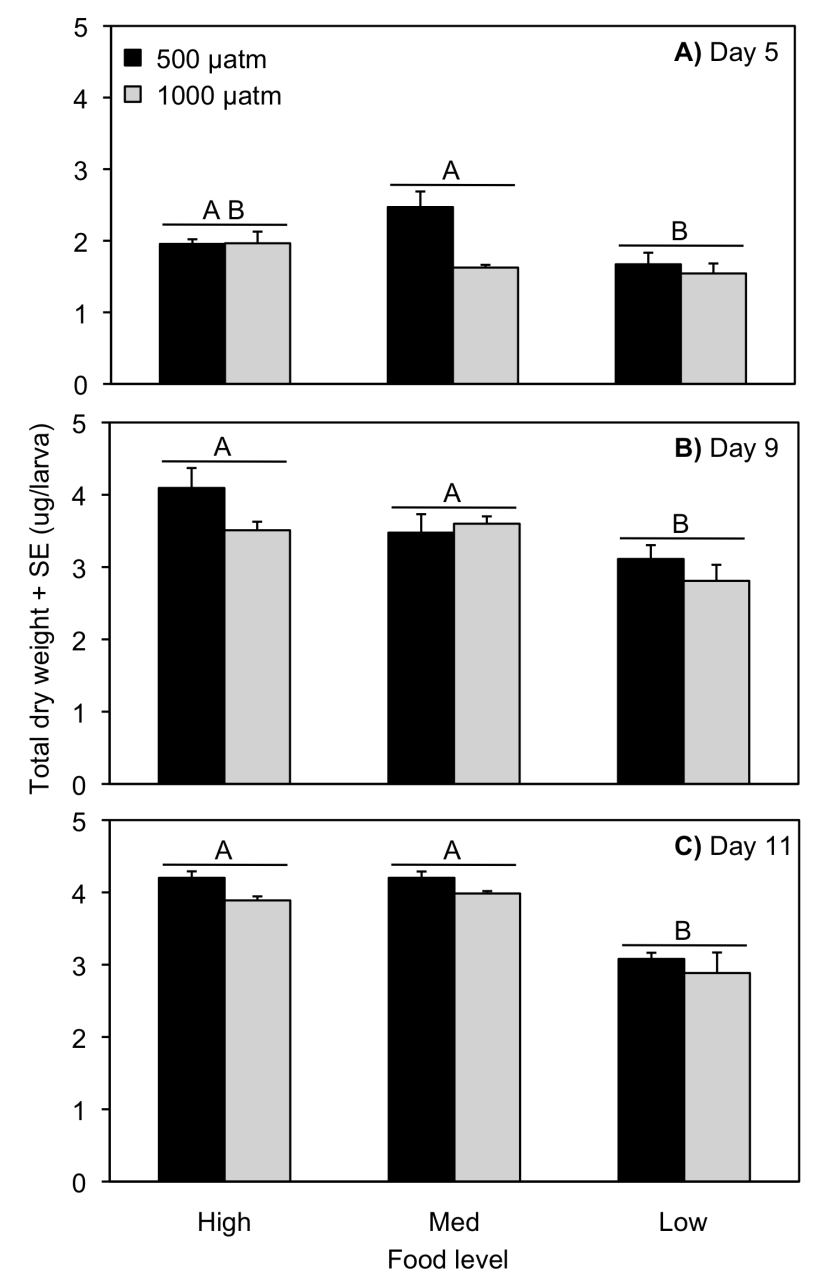

Fig. 2. Effect of $p \mathrm{CO}_{2}$ and food supply on total dry weight in Olympia oyster larvae (Ostrea lurida). Data are weight on (A) day 5, (B) day 9, and (C) day 11 post-larval release in control (black bars) and elevated (grey bars) $p \mathrm{CO}_{2}$ levels. Food levels in each treatment relate to the following concentrations: 100000 cells mL $\mathrm{mL}^{-1}$ (High), 50000 cells mL $\mathrm{mL}^{-1}$ (Med), 10000 cells mL ${ }^{-1}$ (Low), and refer to the density of Isochrysis galbana in each jar per treatment. Values are means across all jar replicates of a given treatment $+1 \mathrm{SE}$. Shared letters above bars indicate food levels that did not differ significantly (Tukey HSD, $p>0.05$ ).

are among the most productive regions in the world's oceans, and their response to ocean acidification is therefore of considerable interest. As discussed above, strong upwelling brings nutrient and $p \mathrm{CO}_{2}$-rich water to shallow nearshore environments (Feely et al., 2008; Kudela et al., 2008). Plentiful nutrients fuel rapid population growth of phytoplankton, which operate as a food source for larvae while simultaneously drawing down $p \mathrm{CO}_{2}$ concentrations (Kudela et al., 2008). The timescale of the draw down can also be important: in the initial stages of upwelling, phytoplankton communities may still be in the early stages of population growth, and may not have yet reached high abundance. Under such conditions, 


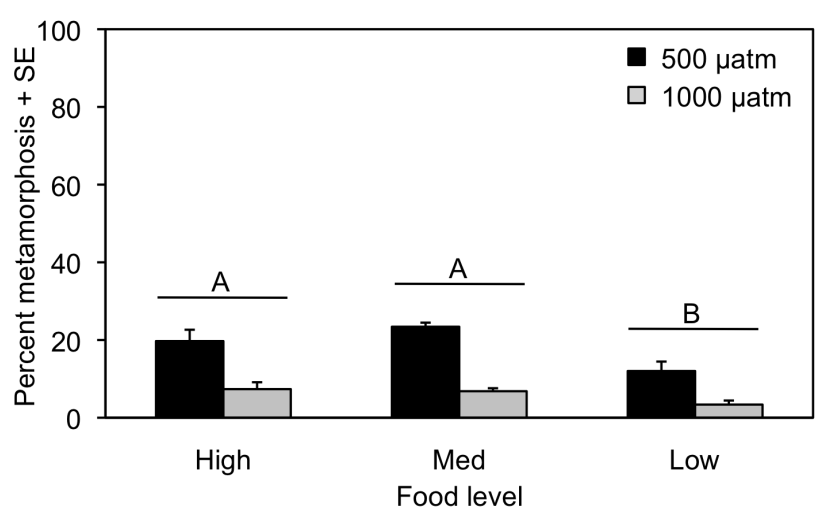

Fig. 3. Effect of $p \mathrm{CO}_{2}$ and food supply on percent metamorphosis in Olympia oysters (Ostrea lurida). Data are the percent of larvae that metamorphosed and settled in control (black bars) and elevated (grey bars) $p \mathrm{CO}_{2}$ levels. Food levels in each treatment relate to the following concentrations: 100000 cells $\mathrm{mL}^{-1}$ (High), 50000 cells $\mathrm{mL}^{-1}$ (Med), 10000 cells $\mathrm{mL}^{-1}$ (Low), and refer to the density of Isochrysis galbana in each jar per treatment. Values are averaged across all jar replicates of each larval $p \mathrm{CO}_{2}$ treatment +1 SE. Shared letters above bars indicate food levels that did not differ significantly (Tukey HSD, $p>0.05$ ).

low pH may accompany low food supply for larvae, whereas in days hence, the opposite pattern may arise. Thus, during the strong upwelling season along the northern California coast, which typically occurs from May-August, limited food might often accompany high $p \mathrm{CO}_{2} / \mathrm{low} \mathrm{pH}$ conditions, and vice versa. Moreover, upwelled waters have been documented to enter the mouth of bays and estuaries, including those in Oregon and California (e.g., Smith and Hollibaugh, 1997; Barton et al., 2012; A. D. Russell, unpublished data). In these instances, even species such as oysters, whose larvae spend much of their planktonic existence within restricted bodies of water, can experience variable combinations of food and $\mathrm{pH}$.

Whether due to temporally varying upwelling phenomena or other processes, many organisms experience temporary periods of stress and/or reduced nutrition during early development with consequent effects on succeeding performance and life history trajectories (Phillips and Gaines, 2002). Our study revealed that low food supply and elevated $p \mathrm{CO}_{2}$ can each lead to decreased oyster larval growth, weight, and percent metamorphosis. However, the effect of elevated $p \mathrm{CO}_{2}$ concentrations on each response did not depend upon the food supply. Conversely, we found that a benign food environment (i.e., one in which food is not limiting) can partially ameliorate the negative effects of larval exposure to high $p \mathrm{CO}_{2}$ conditions. Melzner et al. (2011) found similar results of high $p \mathrm{CO}_{2}$ and reduced food levels on adult mussels. In this case, shell growth was lower in the high $p \mathrm{CO}_{2}$ and low food treatments, but the effect of $p \mathrm{CO}_{2}$ on shell growth did not depend upon the food level. Thomsen et al. (2013) inves- tigated the effects of food supply and ocean acidification on an earlier life stage of the same mussel species, and juvenile mussels were able to overcome exposure to high $p \mathrm{CO}_{2}$ in high resource environments. The response of juvenile mussels to these interacting stressors could conceivably change if individuals were exposed to varying resources and high $p \mathrm{CO}_{2}$ during the larval stage.

Previous work demonstrated that larval carry-over effects (also referred to as latent effects; Pechenik, 2006) resulted in a magnified, negative response in juvenile Olympia oysters, and effects persisted well into juvenile life (Hettinger et al., 2012, 2013). A similar trend was exhibited in this study with high $p \mathrm{CO}_{2}$ having a much larger effect on percent metamorphosis $(70 \%)$ than larval growth $(5-14 \%)$. The detected reduction in percent metamorphosis might have resulted from larvae starting the energetically expensive process of metamorphosis with depleted energy (i.e., protein and lipid) reserves. Carry-over effects often arise through energetic deficits accrued in prior life history phases. By the completion of the larval phase, oysters exposed to acidified conditions may reach metamorphosis in an energy-depleted state. Many life processes incur metabolic costs during the larval life phase, and because metamorphosis is also an energetically demanding process (e.g., Videla et al., 1998), any energetic deficits accumulated during the larval phase could be magnified in subsequent life phases. The magnitude of carry-over effects might depend in part on the mode of larval development, especially dependence on exogenous versus endogenous food supply. Olympia oysters are a brooding species that rely on external resources during larval development. Planktotrophic species such as this might be more strongly impacted by changes in phytoplankton abundance and quality compared to lecithotrophic species that are provided with a source of nutrition upon larval release. However, since the maternal environment has been shown to influence offspring performance (Marshall, 2008), any stress from high $p \mathrm{CO}_{2}$ conditions or altered food supply might equally impact planktotrophic and lecithotrophic species directly or indirectly through maternal effects. Early life stages often act as population bottlenecks (Gosselin and Qian, 1997); thus, adult demographics can be influenced by larval carry-over effects that persist into juvenile and adult life.

Our results suggest that Olympia oyster larvae do not demonstrate the ability to fully counteract exposure to elevated $p \mathrm{CO}_{2}$ conditions in high food environments. Furthermore, low food environments and elevated $p \mathrm{CO}_{2}$ conditions both lead to reduced larval growth and total weights, but these stressors operate additively rather than synergistically. This study shows that even when food supply is abundant, larvae exposed to elevated $p \mathrm{CO}_{2}$ are smaller and weigh less than larvae in ambient conditions. This difference in larval size and weight will likely influence juvenile growth through larval carry-over effects, and could have significant implications for adult populations. 


\section{Supplementary material related to this article is available online at http://www.biogeosciences.net/10/ 6629/2013/bg-10-6629-2013-supplement.pdf.}

Acknowledgements. We thank E. A. Lenz, M. K. Young, E. Ernst, R. Pennington, A. E. Todgham, S. Boles, and J. Newman for assistance with larval culturing. The Tomales Bay Oyster Company provided access to adult oysters. A. Hettinger is grateful for a P. E. O. International Scholar Award. This work was funded by NSF grants OCE-0927255 and OCE-1041089.

Edited by: H.-O. Pörtner

\section{References}

Baker, P.: Review of ecology and fishery of the Olympia oyster, Ostrea conchaphila with annotated biography, J. Shell. Res., 14, 501-518, 1995.

Bakun, A.: Global climate change and intensification of coastal ocean upweling, Science, 247, 198-201, 1990.

Baldwin, B. S. and Newell, R. I. E.: Relative importance of different size food particles in the natural diet of oyster larvae (Crassostrea virginica), Mar. Ecol.-Prog. Ser., 120, 135-145, 1995.

Barton, A., Hales, B., Waldbusser, G. G., Langdon, C., and Feely, R. A.: The Pacific oyster, Crassostrea gigas, shows negative correlation to naturally elevated carbon dioxide levels: implications for near-term ocean acidification effects, Limnol. Oceanogr., 57, 698-710, 2012.

Behrenfeld, M. J., O’Malley, R. T., Siegel, D. A., McClain, C. R., Sarmiento, J. L., Feldman, G. C., Milligan, A. J., Falkowski, P. G., Letelier, R. M., and Boss, E. S.: Climate- driven trends in contemporary ocean productivity, Nature, 444, 752-755, 2006.

Bellerby, R. G. J., Schulz, K. G., Riebesell, U., Neill, C., Nondal, G., Heegaard, E., Johannessen, T., and Brown, K. R.: Marine ecosystem community carbon and nutrient uptake stoichiometry under varying ocean acidification during the PeECE III experiment, Biogeosciences, 5, 1517-1527, doi:10.5194/bg-5-15172008, 2008.

Berge, T., Daugbjerg, N., Andersen, B. B., and Hansen, P. J.: Effect of lowered $\mathrm{pH}$ on marine phytoplankton growth rates, Mar. Ecol.Prog. Ser., 416, 79-91, 2010.

Boidron-Métairon, I.: Larval nutrition, in: Ecology of Marine Invertebrate Larvae, edited by: McEdward, L., CRC Press Inc, Washington DC, USA, 223-248, 1995.

Byrne, M.: Impact of ocean warming and ocean acidification on marine invertebrate life history stages: vulnerabilities and potential for persistence in a changing ocean, Oceanogr. Mar. Biol., 49, $1-42,2011$.

Cai, W. J. and Wang, Y.: The chemistry, fluxes, and sources of carbon dioxide in the estuarine waters of the Satilla and Altamaha Rivers, Georgia, Limnol. Oceanogr., 43, 657-668, 1998.

Caron, D. A. and Hutchins, D. A.: The effects of changing climate on microzooplankton grazing and community structure: drivers, predictions and knowledge gaps, J. Plankton Res., 35, 235-252, 2013.
Comeau, S., Carpenter, R. C., and Edmunds, P. J.: Effects of feeding and light intensity on the response of the coral Porites rus to ocean acidification, Mar. Biol., 160, 1127-1134, 2013.

Diaz, R. J. and Rosenberg, R.: Spreading dead zones and consequences for marine ecosystems, Science, 321, 926-929, 2008.

Dickson, A. G.: Standard potential of the reaction: $\mathrm{AgCl}(\mathrm{s})+1 / 2 \mathrm{H}_{2}(\mathrm{~g})=\mathrm{Ag}(\mathrm{s})+\mathrm{HCl}(\mathrm{aq})$, and the standard acidity constant of the ion HSO4- in synthetic sea water from 273.15 to 318.15 K, J. Chem. Thermodyn., 22, 113-127, 1990.

Dickson, A. G. and Millero, F. J.: A comparison of the equilibrium constants for the dissociation of carbonic acid in seawater media, Deep-Sea Res., 34, 1733-1743, 1987.

Dickson, A. G., Sabine, C. L., and Christian, J. R.: Guide to best practices for ocean $\mathrm{CO}_{2}$ measurements, PICES Special Publication, 3, 191 pp., 2007.

Doney, S. C.: The growing human footprint on coastal and openocean biogeochemistry, Science, 328, 1512-1516, 2010.

Doney, S. C., Fabry, V. J., Feely, R. A., and Kleypas, J. A.: Ocean acidification: the other $\mathrm{CO}_{2}$ problem, Annu. Rev. Mar. Sci., 1, 169-192, 2009.

Edmunds, P. J.: Zooplanktivory ameliorates the effects of ocean acidification on the reef coral Porites spp., Limnol. Oceanogr., 56, 2402-2410, 2011.

Engel, A., Schulz, K. G., Riebesell, U., Bellerby, R., Delille, B., and Schartau, M.: Effects of $\mathrm{CO}_{2}$ on particle size distribution and phytoplankton abundance during a mesocosm bloom experiment (PeECE II), Biogeosciences, 5, 509-521, doi:10.5194/bg-5-5092008, 2008.

Feely, R. A., Sabine, C. L., Hernandez-Ayon, J. M., Ianson, D., and Hales, B.: Evidence for upwelling of corrosive "acidified" water onto the continental shelf, Science, 320, 1490-1492, 2008.

Feely, R. A., Alin, S. R., Newton, J., Sabine, C. L., Warner, M., Devol, A., Krembs C., and Maloy, C.: The combined effects of ocean acidification, mixing, and respiration on $\mathrm{pH}$ and carbonate saturation in an urbanized estuary, Estuar. Coast. Shelf Sci., 88, 442-449, 2010.

García-Reyes, M. and Largier, J.: Observations of increased winddriven coastal upwelling off central California, J. Geophys. Res. 115, C04011, doi:10.1029/2009JC005576, 2010.

Gaylord, B., Hill, T. M., Sanford, E., Lenz, E. A., Jacobs, L. A., Sato, K. N., Russell, A. D., and Hettinger, A.: Functional impacts of ocean acidification in an ecologically critical foundation species, J. Exp. Biol., 214, 2586-2594, 2011.

Gazeau, F., Parker, L. M., Comeau, S., Gattuso, J. P., O’Connor, W. A., Martin, S., Pörtner, H. O., and Ross, P. M.: Impacts of ocean acidification on marine shelled mollusks, Mar. Biol., 160, 2201-2245, 2013.

Giménez, L.: Relationships between habitat conditions, larval traits, and juvenile performance in a marine invertebrate, Ecology, 91, 1401-1413, 2010.

Gosselin, L. A. and Qian, P. Y.: Juvenile mortality in benthic marine invertebrates. Mar. Ecol.-Prog. Ser., 146, 265-282, 1997.

Gruber, N.: Warming up, turning sour, losing breath: ocean biogeochemistry under global change, Philos. Trans. R. Soc. A, 369, 1980-1996, 2011.

Gruber, N., Hauri, C., Lachkar, Z., Loher, D., Fralicher, T. L., and Plattner, G. K.: Rapid progression of ocean acidification in the California Current System, Science, 337, 220-223, 2012. 
Harley, C. D. G, Hughes, A. R., Hultgren, K. M., Miner, B. G., Sorte, C. J. B., Thornber, C. S., Rodriguez, L. F., Tomanek, L., and Williams, S. L.: The impacts of climate change in coastal marine systems, Ecol. Lett. 9, 228-241, 2006

Hauri, C., Gruber, N., Plattner, G. K., Alin, S., Feely, R. A., Hales, B., and Wheeler, P. A.: Ocean acidification in the California Current System, Oceanography, 22, 60-71, 2009.

Hettinger, A., Sanford, E., Hill, T. M., Russell, A. D., Sato, K. N. S., Hoey, J., Forsch, M., Page, H. N., and Gaylord, B.: Persistent carry-over effects of planktonic exposure to ocean acidification in the Olympia oyster, Ecology, 93, 2758-2768, 2012.

Hettinger, A., Sanford, E., Hill, T. M., Lenz, E. A., Russell, A. D., and Gaylord, B.: Larval carry-over effects from ocean acidification persist in the natural environment, Glob. Change Biol., 19, 3317-3316, 2013.

Holcomb, M., McCorkle, D. C., and Cohen, A. L.: Long-term effects of nutrient and $\mathrm{CO}_{2}$ enrichment on the temperate coral $\mathrm{As}$ trangia poculata (Ellis and Solander, 1786), J. Exp. Mar. Biol. Ecol., 386, 27-33, 2010.

IPCC: Intergovernmental Panel on Climate Change, Summary for Policymakers, Cambridge University Press, Cambridge, 2007.

Kimbro, D. L., Largier, J., and Grosholz, E. D.: Coastal oceanographic processes influence the growth and size of a key estuarine species, the Olympia oyster, Limnol. Oceanogr., 54, 1425-1437, 2009.

Kroeker, K. J., Kordas, R. L., Crim, R. N., and Singh, G. G.: Metaanalysis reveals negative yet variable effects of ocean acidification on marine organisms, Ecol. Lett., 13, 1419-1434, 2010.

Kroeker, K. J., Kordas, R. L., Crim, R. N., Hendriks, I. E., Ramajo, L., Singh, G. S., and Duarte, C. M.: Impacts of ocean acidification on marine organisms: quantifying sensitivities and interactions with warming, Glob. Change Biol., 19, 1884-1896, 2013.

Kudela, R. M., Banas, N. S., Barth, J. A., Frame, E. R., Jay, D. A., Largier, J. L., Lessard, E. J., Peterson, T. D., and Vander Woude, A. J.: New insights into the controls and mechanisms of plankton productivity in coastal upwelling waters of the northern California Current System, Oceanography, 21, 46-59, 2008.

Kurihara, H., Kato, S, and Ishimatsu, A.: Effects of increased seawater $p \mathrm{CO}_{2}$ on early development of the oyster Crassostrea gigas, Aquat. Biol., 1, 91-98, 2007.

LaVigne, M., Hill, T. M., Sanford, E., Gaylord, B., Russell, A. D., Lenz, E. A., Hosfelt, J. D., and Young, M. K.: The elemental composition of purple sea urchin (Strongylocentrotus purpuratus) calcite and potential effects of $p \mathrm{CO}_{2}$ during early life stages, Biogeosciences, 10, 3465-3477, doi:10.5194/bg-10-3465-2013, 2013.

Lewis, E. and Wallace, D.: Program developed for $\mathrm{CO}_{2}$ system calculations. ORNL/CIAC-105. Oak Ridge, TN: Oak Ridge National Laboratory, US Department of Energy, 1998.

Marshall, D. J.: Transgenerational plasticity in the sea: contextdependent maternal effects across the life history, Ecology, 89, 418-427, 2008.

Mehrbach, C., Culberson, C. H., Hawley, J. E., and Pytkowicz, R. M.: Measurement of the apparent dissociation constant of carbonic acid in seawater at atmospheric pressure, Limnol. Oceanogr., 18, 879-907, 1973.

Melzner, F., Stange, P., Trübenbach, K., Thomsen, J., Casties, I., Panknin, U., Gorb, S. N., and Gutowska, M. A.: Food supply and seawater $p \mathrm{CO}_{2}$ impact calcification and internal shell dissolu- tion in the blue mussel Mytilus edulis, PLoS ONE, 6, e24223, doi:10.1371/journal.pone.0024223, 2011.

Michaelidis, B., Ouzounis, C., Paleras, A., and Pörtner, H. O.: Effects of long-term moderate hypercapnia on acid-base balance and growth rate in marine mussels Mytilus galloprovincialis, Mar. Ecol.-Prog. Ser., 293, 109-118, 2005.

Miller, A. W., Reynolds, A. C., Sobrino, C., and Riedel, G. F.: Shellfish face uncertain future in high $\mathrm{CO}_{2}$ world: influence of acidification on oyster larvae calcification and growth in estuaries, PLoS ONE, 4, e5661, doi:10.1371/journal.pone.0005661, 2009.

Pace, D. A. and Manahan, D. T.: Efficiencies and costs of larval growth in different food environments (Asteroidea: Asterina miniata), J. Exp. Mar. Biol. Ecol., 353, 89-106, 2007.

Parker, L. M., Ross, P. M., and O'Connor, W. A.: Comparing the effect of elevated $p \mathrm{CO}_{2}$ and temperature on the fertilization and early development of two species of oysters, Mar. Biol., 157, 2435-2452, 2010.

Pechenik, J. A.: Larval experience and latent effects - metamorphosis is not a new beginning, Integr. Comp. Biol., 46, 323-333, 2006.

Phillips, N. E.: Effects of nutrition-mediated larval condition on juvenile performance in a marine mussel, Ecology, 83, 2562-2574, 2002.

Phillips, N. E. and Gaines, S. D.: Spatial and temporal variability in sze at settlement of intertidal mytilid mussels from around Pt. Conception, California, Int. J. Invertebr. Reprod. Dev., 41, 171177, 2002.

Pörtner, H. O., Langenbuch, M., and Reipschläger, A.: Biological impact of elevated ocean $\mathrm{CO}_{2}$ concentrations: lessons from animal physiology and earth history, J. Oceanogr., 60, 705-718, 2004.

Reinfelder, J. R.: Carbon dioxide regulation of nitrogen and phosphorus in four species of marine phytoplankton, Mar. Ecol.-Prog. Ser., 466, 57-67, 2012.

Riebesell, U., Schulz, K. G., Bellerby, R. G. J., Botros, M., Fritsche, P., Meyerhöfer, M., Neill, C., Nondal, G., Oschlies, A., Wohlers, J., and Zöllner, E.: Enhanced biological carbon consumption in a high $\mathrm{CO}_{2}$ ocean, Nature, 450, 545-549, 2007.

Ries J. B., Cohen, A. L., and McCorkle, D. C.: Marine calcifiers exhibit mixed responses to $\mathrm{CO}_{2}$-induced ocean acidification, Geology, 37, 1131-1134, 2009.

Rodriguez, J. L., Sedano, F. J., García-Martín, L. O., PérezCamacho, A., and Sánchez, J. L.: Energy metabolism of newly settled Ostrea edulis spat during metamorphosis, Mar. Biol., 106, 109-111, 1990.

Rose, J. M., Feng, Y., Gobler, C. J., Gutierrez, R., Hare, C. E., Leblanc, K., and Hutchins, D. A.: Effects of increased $p \mathrm{CO}_{2}$ and temperature on the North Atlantic spring bloom. II. Microzooplankton abundance and grazing, Mar. Ecol.-Prog. Ser., 388, 27-40, 2009.

Rossoll, D., Bermúdez, R., Hauss, H., Schulz, K. G., Riebesell, U., Sommer, U., and Winder, M.: Ocean acidification-induced food quality deterioration constrains trophic transfer, PLoS ONE, 7, e34737, doi:10.1371/journal.pone.0034737, 2012.

Sabine, C. L., Feely, R. A., Gruber, N., Key, R. M., Lee, K., Bullister, J. L., Wanninkhof, R., Wong, C. S., Wallace, D. W. R., Tilbrook, B., Millero, F. J., Peng, T. H., Kozyr, A., Ono, T., and Rios, A. F.: The oceanic sink for anthropogenic $\mathrm{CO}_{2}$, Science, 305, 367-371, 2004. 
Smith, S. V. and Hollibaugh, J. T.: Annual cycle of interannual variability of ecosystem metabolism in a temperate climate embayment, Ecol. Monogr., 67, 509-533, 1997.

Snyder, M. A., Sloan, L. C., Diffenbaugh, N. S., and Bell, J. L.: Future climate change and upwelling in the California Current, Geophys. Res. Lett., 30, 1823-1826, 2003.

Strathmann, M. F.: Reproduction and development of marine invertebrates of the Northern Pacific coast, University of Washington Press, Seattle, 1987.

Talmage, S. C. and Gobler, C. J.: The effects of elevated carbon dioxide concentrations on the metamorphosis, size and survival of larval hard clams (Mercenaria mercenaria), bay scallops (Argopecten irradians), and Eastern oysters (Crassostrea virginica), Limnol. Oceanogr., 54, 2072-2080, 2009.

Talmage, S. C. and Gobler, C. J.: Effects of $\mathrm{CO}_{2}$ and the harmful alga Aureococcus anophagefferens on growth and survival of oyster and scallop larvae, Mar. Ecol.-Prog. Ser., 464, 121-134, 2012.

Thompson, P. A., Guo, M., and Harrison, P. J.: The influence of irradiance on the biochemical composition of three phytoplankton species and their nutritional value for larvae of the Pacific oyster (Crassostrea gigas), Mar. Biol., 117, 259-268, 1993.

Thomsen, J., Casties, I., Pansch, C., Körtzinger, A., and Melzner, F.: Food availability outweighs ocean acidification effects in juvenile Mytilus edulis: laboratory and field experiments, Glob. Change Biol., 19, 1017-1027, 2013.
Underwood, A. J.: Experiments in ecology: their logical design and interpretation using analysis of variance, Cambridge University Press, Cambridge, 1997.

Vargas, C. A., Manríquez, P. H., and Navarrete, S. A.: Feeding by larvae of intertidal invertebrates: assessing their potential position in pelagic food webs, Ecology, 87, 444-457, 2006.

Vargas, C. A., De La Hoz, M., Aguilera, V., San Martín, V., Manríquez, P. H., Navarro, J. M., Torres, R., Lardies, M. A., and Lagos, N. A.: $\mathrm{CO}_{2}$-driven ocean acidification reduces larval feeding efficiency and change food selectivity in the mollusk Concholepas concholepas, J. Plankton Res., 35, 1059-1068, 2013.

Videla, J. A., Chaparro, O. R., Thompson, R. J., and Concha, I. I.: Role of biochemical energy reserves in the metamorphosis and early juvenile development of the oyster Ostrea chilensis, Mar. Biol., 132, 635-640, 1998.

Waldbusser, G. G., Bergschneider, H., and Green, M. A.: Sizedependent $\mathrm{pH}$ effect on calcification in post-larval hard clam Mercenaria spp., Mar. Ecol.-Prog. Ser., 417, 171-182, 2010.

Waldbusser, G. G., Brunner, E. L., Haley, B. A., Hales, B., Langdon, C., and Prahl, F. G.: A developmental and energetic basis linking larval oyster shell formation to acidification sensitivity, Geophys. Res. Lett., 40, 2171-2176, 2013.

Wood, H. L., Spicer, J. I., and Widdicombe, S.: Ocean acidification may increase calcification rates, but at a cost, Proc. R. Soc., B, 275, 1767-1773, 2008. 